\title{
Immunity peculiarities of neonates in case of perinatal pathology
}

\author{
0. S. Godovanets, A. B. Mihalchan, O. I. Godovanets, V. V. Bezruk, T. 0. Bezruk
}

Higher State Educational Establishment of Ukraine "Bukovinian State Medical University", Chernivtsi

Key words: newborns, perinatology, hypoxia, immune system.

\section{Zaporozhye} medical journal 2018; 20 (1), 82-85 DOI: 10.14739/2310-1210 2018.1.122001

\section{E-mail:} godovanec.oleksij@ bsmu.edu.ua
The immune system as one of the regulating systems of the body determined peculiarities of child adaptation after birth stipulating physiology of adaptation or perinatal pathology formation.

Objective: to study peculiarities of immunological indices in case of neonates' perinatal pathology to detect their role in pathogenesis and formation of diseases severity.

Materials and methods. The group of term infants with clinical signs of perinatal pathology (173 individuals) was examined. They were divided into two groups: group A included those with diagnosed severe forms of diseases (121 individuals), and group $B$ included 52 infants with general moderate severity of perinatal pathology. The group of comparison included 82 newborns without substantial adaptive deviations after birth. IL $1 \mathrm{~b}$ and IL6 levels were examined by means of immunofluorescence method "Clonospectr" using the reagents produced by "ProCon". Absolute and relative amount of CD2+-associated T and NK-lymphocytes, CD14+-associated monocytes, CD15+-associated neutrophils, CD19+-associated B-lymphocytes and CD54+-associated ICAM-1 cells were determined by means of immunofluorescence method "Status" using the set of monoclonal and polyclonal antibodies produced by "Sorbent". The data obtained were statistically processed with the application of applied programs package used for medical-biological studies Statgraphics Centurion XVI.I [2011] on the personal computer Pentium MMX CPU.

Results. The results obtained were indicative of considerable changes in the immune system indices in newborns under conditions of birth stress and hypoxia. It has been found that a term newborn has a special different from that of adults biologically mediated state of immune system, that can determine both the development of physiological adaptation and under certain circumstances excessive reactions of systemic inflammation, autoimmune processes and destruction of tissues. One of the evidences of immune system components participation in perinatal pathology pathogenesis is detected correlation between immune disorders severity and clinical manifestation of diseases, as well as immune indices normalization in a long-term organism adaptation formation.

Conclusions. Based on the data obtained it has been concluded that immune system status determination is reasonable for diagnostics of disadaptation syndrome severity in early neonatal period.
Кнючові слова: новонароджені, перинатальна патологія, гіпоксія, імунна система.

Запорізький медичний журнал. - 2018. -

T. 20, № 1(106). C. 82-85

\section{Особливості імунітету в новонароджених при перинатальній патології}

\author{
О. С. Годованець, А. Б. Мігалчан, О. І. Годованець, В. В. Безрук, Т. О. Безрук
}

Імунна система як одна з регулюючих систем організму визначає особливості адаптації дитини після народження, зумовлюючи фізіологію адаптації або формування перинатальної патології.

Мета роботи - вивчити особливості імунологічних показників у новонароджених при перинатальній патології для визначення їхньої ролі в патогенезі та формуванні ступеня тяжкості захворювань.

Матеріали та методи. Обстежили групу доношених новонароджених дітей, які мали клінічні ознаки перинатальної патології (173 особи). До підгрупи А ввійшли діти, в яких діагностовані тяжкі форми захворювань (121 особа), до підгрупи В - 52 дитини, які мали загальний стан середньої важкості за умов перинатальної патології. Групу порівняння становили 82 новонароджені, які не мали суттєвих відхилень адаптації після народження. Дослідження рівня IL $1 \mathrm{~b}$ та IL6 виконали методом імунофрлуоресценції «Клоноспектр» із використанням реактивів ООО «ProCon». Визначення абсолютної та відносної кількості CD2+-асоційованих T та NK-лімфоцитів, CD14+-асоційованих моноцитів, CD15+асоційованих нейтрофрілів, CD19+-асоційованих В-лімфоцитів і CD54+-асоційованих клітин ICAM-1 здійснено методом імунофрлуоресценції «Статус» із застосуванням «Набору моноклональних і поліклональних антитіл» ООО «Сорбент». Статистичне опрацювання даних здійснили з застосуванням пакета прикладних програм для проведення медико-біологічних досліджень Statgraphics Centurion XVI.I [2011] на персональному комп'ютері Pentium MMX CPU.

Результати. Результати, що отримали, засвідчили наявність суттєвих змін показників імунної системи в новонароджених за умов пологового стресу та гіпоксії. Відзначено: доношена новонароджена дитина має особливий, що відрізняється від дорослих, біологічно зумовлений стан імунної системи, котра може визначати як розвиток фізіологічної адаптації, так і, за певних обставин, надмірні реакції системного запалення, автоімунних процесів і деструкції тканин. Одним із доказів участі ланок імунної системи в механізмах розвитку перинатальної патології є виявлений нами кореляційний зв'язок між тяжкістю імунологічних розладів і клінічною картиною захворювань, а також нормалізація імунних показників при фрормуванні довготривалої адаптації організму.

Висновки. На підставі даних зробили висновок щодо доцільності визначення стану імунної системи для діагностики ступеня тяжкості дизадаптаційних синдромів у ранньому неонатальному періоді.
Ключевые слова: новорожАенные, перинатальная патология,

гипоксия, иммунная система.

\section{Особенности иммунитета у новорожденных при перинатальной патологии}

\author{
А. С. Годованец, А. Б. Мигалчан, О. И. Годованец, В. В. Безрук, Т. А. Безрук
}

Иммунная система как одна из регулирующих систем организма определяет особенности адаптации ребенка после рождения, вызывая физиологию адаптации или формирование перинатальной патологии. 
Цель работы - изучить особенности иммунологических показателей у новорожденных при перинатальной патологии для определения их роли в патогенезе и формировании степени тяжести заболеваний.

Материалы и методы. Обследована группа доношенных новорожденных детей, которые имели клинические признаки перинатальной патологии (173 человека). В подгруппу А вошли дети, у которых диагностирована тяжелая форма заболевания (121 человек), в подгруппу В - 52 ребенка, которые имели общее состояние средней тяжести в условиях перинатальной патологии. Группу сравнения составили 82 новорожденных, не имеющие существенных отклонений адаптации после рождения. Исследование уровня IL1b и IL6 проведено методом иммунофрлуоресценции «Клоноспектр» с использованием реактивов ООО «ProCon». Определение абсолютного и относительного количества $\mathrm{CD} 2^{+}-$ассоциированных T и NK-лимфоцитов, CD14+-ассоциированных моноцитов, CD15-ассоциированных нейтрофилов, CD19+-ассоциированных В-лимфоцитов и CD54+-ассоциированных клеток ИСАМ-1 осуществлено методом иммунофлуоресценции «Статус» с применением «Набора моноклональных и поликлональных антител» ООО «Сорбент». Статистическая обработка полученных данных проведена с применением пакета прикладных программ для проведения медико-биологических исследований Statgraphics Centurion XVI.I [2011] на персональном компьютере Pentium MMX CPU.

Результаты. Полученные результаты показали наличие существенных изменений показателей иммунной системы у новорожденных в условиях родового стресса и гипоксии. Отмечено, что доношенный новорожденный ребенок имеет особое, в отличии от взрослых, биологически обусловленное состояние иммунной системы, что может определять как развитие физиологической адаптации, так, и при определенных обстоятельствах, чрезмерные реакции системного воспаления, аутоиммунные процессы и деструкцию тканей. Одним из доказательств участия звеньев иммунной системы в механизмах развития перинатальной патологии является обнаруженная нами корреляционная связь между тяжестью иммунологических расстройств и клинической картиной заболеваний, а также нормализация иммунных показателей при формировании долговременной адаптации организма.

Выводы. На основе полученных данных сделан вывод о целесообразности определения состояния иммунной системы для диагностики степени тяжести дизадаптационных синдромов в раннем неонатальном периоде.

\section{Introduction}

Lymphocytes multiplication and differentiation are considered to be the functions of immune system that is associated with mediators of intercellular communication production and contact connection with adhesion molecules participation. Immune response mediators are able to penetrate through undamaged blood-brain barrier and change functional activity of "hypothalamus-pituitary-adrenal cortex" system due to direct influence on the processes of sanogenesis and pathogenesis in a child's organism in conditions of birth oxidative stress (OS) [2,4-6].

Immune system as one of the regulating systems of the body stipulates short-term and long-term adaptation after birth formation. Imbalance of immune system components in conditions of birth stress and hypoxia causes system of organs functional disorders development and perinatal pathology formation.

\section{Objective}

To study peculiarities of immunological indices in case of neonates' perinatal pathology to detect their role in pathogenesis and formation of diseases severity.

\section{Materials and methods}

The group of term infants with clinical signs of perinatal pathology (173 individuals) was examined. They were divided into two groups: group A included infants with diagnosed severe forms of diseases (121 individuals), and group $B$ included 52 infants with general moderate severity in conditions of perinatal pathology. The group of comparison included 82 newborns without substantial adaptive deviations after birth.

IL1b and IL6 levels were examined by means of immunofluorescence method "Clonospectr" using the reagents produced by "ProCon". Absolute and relative amount of $\mathrm{CD}^{+}$-associated T- and NK-lymphocytes, CD14+-associated monocytes, CD15+-associated neutrophils, CD19+-associated B-lymphocytes and CD54+-associated ICAM-1 cells were determined by means of immunofluorescence method "Status" using the set of monoclonal and polyclonal antibodies produced by "Sorbent".

The data obtained were statistically processed with the application of applied programs package used for medical-biological studies "Statgraphics Centurion XVI.I" [2011] on the personal computer Pentium MMX CPU.

\section{Results and discussion}

The results of the conducted clinical-statistical investigation detected that severity of condition of newborns from group A at birth was caused by: severe asphyxia in 24 cases $(19.0 \%)$, moderate asphyxia with further deterioration of the condition - in 52 cases $(41.3 \%)$, hemolytic disease of newborns - in 22 cases (17.5\%), manifestation of intrauterine infection - in 14 cases $(11.1 \%)$, inborn pneumonia - in 2 cases (1.6\%), Pierre Robin syndrome in 2 cases $(1.6 \%)$. Adaptive disorders among infants of group B during the first week of life were caused by: neonatal encephalopathy - in 42 cases (80.9\%), CNS traumatic damage - in 5 cases $(9.5 \%)$, hemolytic disease of newborns - in 4 cases $(7.8 \%)$ and manifestation of intrauterine infection - in 1 case $(1.9 \%)$.

An average assessment of group A newborns at the first minute of life was $5.0 \pm 0.21$ point, at the fifth minute $-5.9 \pm 0.23$ with probable difference as compared to babies from the control group $(7.1 \pm 0.03$ and $7.7 \pm 0.09$ point respectively), $P<0.05$. The assessment of newborns from group $B$ at the first minute of life was $7.1 \pm 0.08$ point, at the fifth minute $-7.8 \pm 0.11$ that was significantly higher than those of infants from group $A$, but did not differ from the control group.
Запорожский медицинский журнал. - 2018. T. 20, № 1(106). C. $82-85$ 
The results of the studies were indicative of the fact that considerable differences in the level of proinflammatory cytokines IL1b and IL6 were manifested in newborns of the groups compared according to the severity of their condition which indicates a certain difference of cytokine reaction. Thus, in case of physiological course of early neonatal period in infants the level of IL $1 \mathrm{~b}$ was $16.9 \pm 1.54$ $\mathrm{pcg} / \mathrm{ml}$, IL6 level $-1.1 \pm 0.08 \mathrm{pcg} / \mathrm{ml}$, with moderate pathology $-27.9 \pm 1.48 \mathrm{pcg} / \mathrm{ml}$ and $4.3 \pm 0.25 \mathrm{pcg} / \mathrm{ml}$ respectively; with severe condition $-21.2 \pm 0.39 \mathrm{pcg} / \mathrm{ml}$ and $2.2 \pm 0.10 \mathrm{pcg} / \mathrm{ml}$ respectively $(P<0.05)$.

One of the most important functions of the cytokine system is insurance of coordinated activity of immune, endocrine and nervous systems in a complex response of the body to stressful situation. Cytokine effect is implemented through their interrelation with specific cells membrane receptors $[3,7]$.

It should be noted that according to scientific literature evidence $[1,4]$, in spite of cytokine activation, moderate changes of their level in newborns are not associated with realization of hypoxia, inflammation, endotoxicosis or multiple-organ failure clinical signs. Support of systemic homeostasis in these cases is provided by a complex of mechanisms of reverse connection (proliferation and differentiation of lymphocytes) and increased level of antiinflammatory cytokines in the blood serum.

The indices of immune system cells receptor activity depending on the severity of newborns condition demonstrated that considerable deviations from the norm in infants was characteristic of a relative amount of $\mathrm{CD}^{+}$-associated T- and NK-lymphocytes - the indices increased according to pathology severity increasing. Relative amount of CD14+-associated monocytes in children was characterized by a tendency to increase in case of moderate condition and reduction of the index in case of its increase. Relative amount of $\mathrm{CD} 15^{+}$-associated neutrophils increased in newborns with moderate disorders of their general condition with probable increase of the index in case of severe pathology. Relative amount of CD19+associated B-lymphocytes is characterized by certain reduction of the index in newborns with moderate pathology and significant increase in severe pathology. Moreover, considerable differences in a relative amount of CD54 ${ }^{+}$ cells (ICAM-1) were observed in newborns according to their general condition degree of severity. If there were any clinical signs of moderate pathology a significant increase in $\mathrm{CD} 54^{+}$index was found, the severity of condition against the background of perinatal pathology was associated with its significant low level as to children from the group of comparison.

Correlation dependence between the presented indices of the immune system demonstrated the greatest number of correlation links in early neonatal period in infants with satisfactory condition. The adaptation processes intensity in moderate perinatal pathology was associated with changes of correlation coefficients and their vector. In case of severe pathology strong correlation disappeared, the new ones were formed with negative values provoked by immune imbalance, decreased regulatory capacity of the immune system and general adaptation processes of the organism.

\section{Conclusions}

1. An increasing level of IL $1 \mathrm{~b}$ and IL6 cytokines is determined in term neonates which characterizes the activation of anti-inflammatory mechanisms in the body in conditions of birth stress.

2. Severity of perinatal pathology in infants as compared to the control is associated with an increased level of IL $1 \mathrm{~b}$ and IL6 in case of moderate severity and decreased level of the indices in case of severe condition of a neonate which in this case is indicative of insufficient organism compensatory mechanisms in severe forms of perinatal pathology.

Prospects of further studies are connected with investigation of issues concerning metabolic correction to normalize mechanisms of organism adaptation in perinatal pathology.

\section{References}

[1] Field, C. J. (2005) The immunological components of human milk and their effect on immune development in infants. J Nutr, 135(1), 1-4.

[2] Hanson, L. A., Korotkova, M., Lundin, S., Håversen, L., Silfverdal, S. A Mattsby-Baltzer, I., et al. (2003) The transfer of immunity from mother to child. Annals of the New York Academy of Sciences, 987(1), 199-206. doi: 10.1111/j.1749-6632.2003.tb06049.x

[3] Daminova, M. A., Safina, A. I., \& Khamzina, G. A. (2013) Novoe v klassifikacii i diagnostike ostrogo povrezhdenijya pochek u novorozhdennyh [New in the classification and diagnosis of acute kidney injury (AKI) newborn]. Vestnik sovremennoj klinicheskoj mediciny, 6(6), 62-70. [in Russian].

[4] Shunko, E. E., Omelchenko, L. V., Putkaradze, R. V., \& Laksha, O. T. (2014) Osoblyvosti imunnoi systemy u novonarodzhenykh v krytychnomu stani, vplyv na stan zdorovia v rannomu dytynstvi [Features of the immune system in newborns in critical condition, the impact on health in early childhood]. Zbirnyk naukovykh prats spivrobitnykiv NMAPO im. P.L. Shupyka, 23(3), 395-407. [in Ukrainian].

[5] Tonni, G., Leoncini, S., Signorini, C., Ciccoli, L., \& De Felice, C. (2014) Pathology of perinatal brain damage: background andoxidative stress markers. Arch Gynecol Obstet, 290(1), 13-20. doi: 10.1007/s00404014-3208-6.

[6] Aversa, S., Pellegrino, S., Barberi, I., Reiter, R. J., \& Gitto, E. (2012) Potential utility of melatonin as an antioxidant during pregnancy and in the perinatal period. J Matern Fetal Neonatal Med, 25(3), 207-221. doi: 10.3109/14767058.2011.573827.

[7] Perrone, S., Tataranno, M. L., Negro, S., Longini, M., Marzocchi, B., Proietti, F., et al. (2010) Early identification of the risk for free radical-related diseases in preterm newborns. Early Hum Dev, 86(4), 241-4. doi: 10.1016/j.earlhumdev.2010.03.008.

\section{Information about authors:}

Godovanets 0. S., MD, PhD, Assistant, Department of Pediatrics, Neonatology and Perinatology Medicine, Higher State Educational Establishment of Ukraine "Bukovinian State Medical University", Chernivtsi.

ResearcherID: B-1224-2017.

Mihalchan A. B., MD, Assistant, Department of Pediatrics, Neonatology and Perinatology Medicine, Higher State Educational Establishment of Ukraine "Bukovinian State Medical University", Chernivtsi.

Godovanets 0. I., MD, PhD, DSci, Associate Professor, Department of Surgical and Pediatric Stomatology, Higher State Educational Establishment of Ukraine "Bukovinian State Medical University", Chernivtsi.

Bezruk V. V., MD, PhD, Associate Professor, Department of Pediatrics, Neonatology and Perinatology Medicine, Higher State Educational Establishment of Ukraine "Bukovinian State Medical University", Chernivtsi.

Researcher ID: B-8621-2017.

Bezruk T. O., MD, PhD, Associate Professor, Department of Internal Medicine, Higher State Educational Establishment of Ukraine "Bukovinian State Medical University", Chernivtsi. Researcher ID: c-9965-2017. 


\section{Відомості про авторів:}

Годованець О. С., канд. меА. наук, асистент каф. педіатрії,

неонатології та перинатальної медицини, ВАНЗ України

"Буковинський Аержавний медичний університет", м. Чернівці.

Мігалчан А. Б., асистент каф. педіатрії, неонатології

та перинатальної меАицини, ВАНЗ України “Буковинський

Аержавний медичний університет", м. Чернівці.

Годованець О. І., А-р меА. наук, Аоцент каф. хірургічної

та Аитячої стоматології, ВАНЗ України “Буковинський Аержавний медичний університет", м. Чернівці.

Безрук В. В., канА. меА. наук, Аоцент каф. педіатрії, неонатології та перинатальної медицини, ВАНЗ України “Буковинський Аержавний медичний університет", м. Чернівці.

Researcher ID: B-8621-2017.

Безрук Т. О., канА. меА. наук, Аоцент каф. внутрішньої медицини та інфекційних хвороб, ВАНЗ України “Буковинський державний медичний університет", м. Чернівці.

Researcher ID: c-9965-2017.

\section{Сведения об авторах:}

Годованец А. С., канА. меА. наук, ассистент каф. педиатрии, неонатологии и перинатальной медицины, ВГУЗ Украины "Буковинский государственный меАицинский университет", г. Черновцы.

Мигалчан А. Б., ассистент каф. педиатрии, неонатологии и перинатальной меАицины, ВГУЗ Украины “Буковинский государственный медицинский университет", г. Черновцы. Годованец О. И., А-р меА. наук, Аоцент каф. хирургической и Аетской стоматологии, ВГУЗ Украины “Буковинский государственный медицинский университет", г. Черновцы.

Безрук В. В., канА. меА. наук, Аоцент каф. педиатрии, неонатологии и перинатальной медицины, ВГУЗ Украины "Буковинский государственный медицинский университет", г. Черновцы.

Безрук Т. А., канА. меА. наук, Аоцент каф. внутренней меАицины и инфекционных болезней, ВГУЗ Украины "Буковинский государственный медицинский университет", г. Черновцы.

Conflicts of Interest: authors have no conflict of interest to declare. Конфлікт інтересів: віАсутній.

Надійшка Ао редакції / Received: 11.07.2017

Після Аоопрацювання / Revised: 04.09.2017

Прийнято Ао Аруку / Accepted: 12.10.2017 